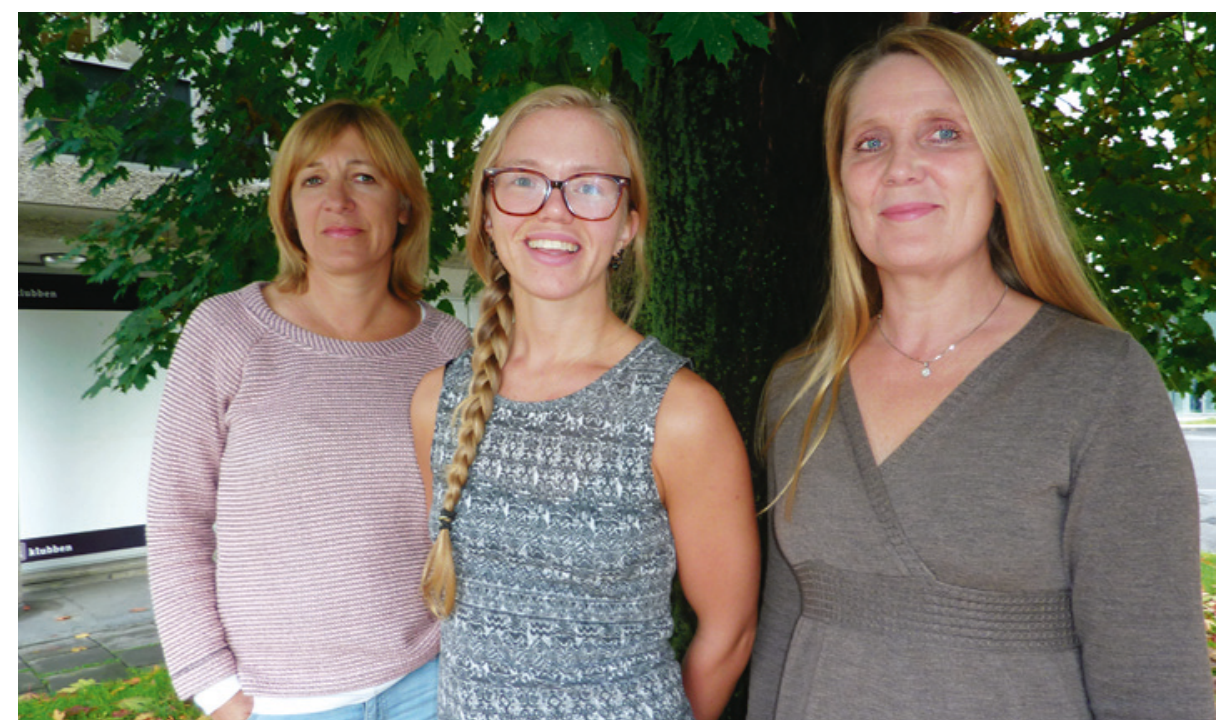

Marte Handal (til venstre), Brit Solvor Riska og Svetlana Skurtveit. Foto: Siri Haugsnes
Ordforklaringer

Benzodiazepiner: En gruppe legemidler som brukes som angstdempende, sovemiddel eller i behandling av epilepsi. Det finnes flere forskjellige benzodiazepiner på det norske markedet. Noen av de mest kjente er diazepam (Vival, Valium, Stesolid), oksazepam (Sobril, Alopam), klonazepam (Rivotril) og flunitrazepam (tidligere i salg som Flunipam og Rohypnol).

Z-hypnotika: Kalles også benzodiazepinliknende legemidler og brukes som sovemedisin. I Norge er det sovemidlene med virkestoff zopiklon (Imovane, Zopiclone, Zopiklon, Zopitin) og zolpidem (Stilnoct, Stilnox, Zolpidem) som er i salg.

Kohortstudie: En prospektiv unders $ø$ kelse av en gruppe mennesker over tid for å se hvem som utvikler sykdom, eller som i den aktuelle studien, får utlevert et legemiddel på apotek.

\title{
Lite bruk av angstdempende legemidler blant gravide i Norge
}

Få gravide bruker benzodiazepiner og z-hypnotika i Norge, og det ble brukt mindre under graviditet enn før og etter svangerskapet.

Søvnproblemer og angst er vanlig, også blant gravide. Vi vet lite om hvordan angstdempende medisiner og sovemedisiner påvirker fosteret. Derfor anbefales kvinner å ikke bruke dem under svangerskap annet enn på sterk indikasjon. I en nylig publisert studie beskrives bruken av benzodiazepiner og z-hypnotika blant gravide i Norge (1). Dette er førsteforfatter Brit Solvor Riska sin første publikasjon.

Kohorten besto av alle gravide i Norge i perioden 2004-10, nesten 350000 kvinner. Forskerne fikk data ved å koble Medisinsk fødselsregister og Reseptregisteret. 5135 kvinner $(1,5 \%)$ fikk utlevert et benzodiazepin eller et z-hypnotikum i løpet av graviditeten. De fleste brukte medisinene kortvarig, og rundt $70 \%$ hentet ut slike legemidler kun én gang. Bruken var sjeldnere under graviditet sammenliknet med perioden før og etter svangerskapet. Gruppen som brukte legemidlene var som helhet eldre, hadde sjeldnere partner, røyket mer og hadde oftere kronisk sykdom enn dem som ikke brukte slike legemidler. Av brukerne fikk rundt $20 \%$ også forskrevet et opioid og rundt $20 \%$ et antidepressivum i tillegg.

- Denne studien viser at forskrivning av benzodiazepiner og z-hypnotika under graviditet skjer relativt sjelden i Norge, sier Brit Solvor Riska. - Likevel fikk en del gravide forskrevet slike medisiner i til dels store mengder, og blant disse var samtidig medi- sinering med opioider og/eller antidepressiver vanlig. Dette er den første studien der man kartlegger de gravides doser av disse legemidlene. Studien er et godt utgangspunkt for videre forskning på svangerskap der barnet blir utsatt for slike medikamenter, sier Riska.

\section{$\emptyset$ konom og medisinstudent}

Brit Solvor Riska er medisinstudent på 11. semester ved Universitetet i Oslo. Fra før har hun bachelorgrad i samfunnsøkonomi fra samme universitet. Etter en forelesning med Camilla Stoltenberg det første året på medisinstudiet kom hun i kontakt med Folkehelseinstituttet, og i 2012 tok hun kontakt med Avdeling for legemiddelepidemiologi for å diskutere en studentoppgave med utgangspunkt i data fra Reseptregisteret. Marte Handal, som er forsker og farmakolog, har vært hennes veileder. Øvrige medforfattere er Svetlana Skurtveit, Kari Furu og Anders Engeland.

\section{Lise Mørkved Helsingen}

Tidsskriftet

\footnotetext{
Litteratur

1. Riska BS, Skurtveit S. Furu K et al. Dispensing of benzodiazepines and benzodiazepine-related drugs to pregnant women: a population-based cohort study. Eur J Clin Pharmacol 2014; 70 : 1367-74.
} 